directly by antibiotic pressure, acute-care hospitals with teaching programs or trauma or burn units (ie, with severely ill patients) need to be especially vigilant for increases in nosocomially acquired antimicrobial-resistant pathogens. ${ }^{1}$

Our study reveals some of the potential errors that may be included in state-based passive surveillance systems if appropriate definitions, proficiency testing, and passive reporting validation are not incorporated into the system. Since all or most state-based infectious diseases surveillance systems are initiated passively, these errors, which could cause both inaccuracies and underreporting of pathogens, are likely to occur. Our results suggest that state-based surveillance systems should be assessed periodically for accuracy and completeness of passive reporting and for proficiency at identifying the pathogen sought and its antimicrobial susceptibility. Our data suggest that reporting of VRE and other infectious agents through state-based passive reporting systems may considerably underestimate the incidence of these agents.

\section{REFERENCES}

1. Centers for Disease Control and Prevention, Hospital Infection Control Practices Advisory Committee. Recommendations for preventing the spread of vancomycin resistance. Infect Control Hosp Epidemiol 1995; $16: 105-113$

2. Centers for Disease Control and Prevention. Nosocomial enterococci resistant to vancomycin-United States, 1989-1993. MMWR 1993;42:597-599.

3. Centers for Disease Control and Prevention. Statewide surveillance for antibiotic-resistant bacteria-New Jersey, 1992-1994. MMWR 1995;44:504-506.

4. Centers for Disease Control and Prevention. Assessment of testing for and completeness of reporting of vancomycin-resistant enterococciConnecticut, 1994. MMWR 1996;45:289-291.

5. Tenover FC, Tokars J, Swenson J, Paul S, Spitalny K, Jarvis W. Ability of clinical laboratories to detect antimicrobial agent-resistant enterococci. $J$
Clin Microbiol 1993;31:1695-1699.

6. Kiehlbauch J, Kendle JM, Carison IG, Schoenknecht FD, Plourde JJ. Automated antibiotic susceptibility testing: comparative evaluation of four commercial systems and present state. Clin Lab Med 1989;9:319-340.

7. Paul SM, Finelli L, Crane GL, Spitalny KC. A statewide surveillance system for antimicrobial resistant bacteria: New Jersey. Infect Control Hosp Epidemiol 1995;16:385-390.

8. Boyle P, Parkin DM. Statistical methods for registries. In: Jensen OM, Parkin DM, MacLennan R, Muir CS, Skeet RG, eds. Cancer Registration: Principles and Methods. IARC Scientific Publications no. 95. Lyon, France. International Agency for Research on Cancer; 1991:126-158.

9. Doll R, Smith PG. Comparison between registries: age standardized rates. In: Waterhouse J, Muir C, Shanmugaratnam K, Powell J, eds. Cancer Incidence in Five Continents, vol. IV. IARC Scientific Publications no. 42. Lyon, France: International Agency for Research on Cancer; 1982:671-674.

10. Freund RJ, Littell RC. SAS System for Regression. Cary, NC: SAS Institute; 1987

11. Zabransky RJ, DiNuzzo AR, Huber MB, Woods DL. Detection of vancomycin resistance in enterococci by the Vitek AMS system. Diagn Microbiol Infect Dis 1994;20:113-116.

12. Cahill CK, Rosenberg J. Guideline for prevention and control of antibiotic-resistant microorganisms in California long-term care facilities. $J$ Gerontol Nurs 1996;22:40-47.

13. Shekar R, Chico G, Bass SN, Strozewski K, Biddle J. Household transmission of vancomycin-resistant Enterococcus faecium. Clin Infect Dis 1995;21:1511-1512.

14. Rosenberg J, Tenover FC, Wong J, Jarvis W, Vugia DJ. Are clinical laboratories in California accurately reporting vancomycin-resistant enterococci? J Clin Microbiol 1997;35:2526-2530.

15. Gaynes R, Edwards J. Nosocomial vancomycin resistant enterococci (VRE) in the United States, 1989-1995: the first 1000 isolates. Infect Control Hosp Epidemiol 1996;17(suppl):P18. Abstract 13.

16. Jarvis W, Thornsberry C, Boyce J, Hughes JM. Methicillin-resistant Staphylococcus aureus at children's hospitals in the United States. Pediatr Infect Dis 1985;4:651-655.

17. Shay DK, Maloney SA, Montecalvo M, Banerjee S, Wormser GP Arduino MJ, et al. Epidemiology and mortality risk of vancomycin-resistant enterococcal bloodstream infections. I Infect Dis 1995;172:993-1000.

18. Morris JG, Shay DK, Hebden JN, McCarter RJ Jr, Perdue BE, Jarvis W, et al. Enterococci resistant to multiple antimicrobial agents, including vancomycin. Establishment of endemicity in a university medical center. Ann Intern Med 1995;123:250-259.

\title{
Trends in Nosocomial Pneumonia in Surgical Patients
}

\section{Gina Pugliese, RN, MS Martin S. Favero, PhD}

Crabtree and colleagues from the University of Virginia Department of Surgery, Charlottesville, conducted a study to compare outcome and prognostic factors of pneumonia in surgical patients. They prospectively studied all episodes of nosocomial infection at all sites in 1997 on the surgical services at a single hospital. Pneumonia accounted for 74 of 287 episodes of infection. The crude mortality for pneumonia was $31.1 \%$ versus $12.2 \%$ for all other infections $(P<.001)$. Pneumonia patients had a higher severity of illness compared with those with infections at other sites $(18.7 \pm 0.8$ vs $14.0 \pm 0.5 ; P<.001)$. Crude mortality remained higher in pneumonia patients when compared with an infected control group matched for severity of illness and age (31\% vs $15 \%$; $P=.02)$. Staphylococcus aureus (15\%) was the most common isolate, followed by Pseudomonas aeruginosa (9\%). Resistant gram-positive cocci accounted for $7 \%$ of all isolates, but was associated with a $60 \%$ mortality versus $28 \%$ with other organisms (not significant; $P=.1$ ).

The Acute Physiology and Chronic Health Evaluation (APACHE) II score for patients with resistant gram-positive cocci was $22 \pm 1$ versus $18 \pm 1$ with other organisms $(P=.03)$. Nonsurvivors of pneumonia were older $(58 \pm 2$ vs $51 \pm 3 ; P=.03)$, had a higher APACHE II score $(23 \pm 1$ vs $17 \pm 1 ; P<.001)$, and were diagnosed later in their hospital course $(18 \pm 4$ days vs $11 \pm 1 ; P=.05$ ) compared with survivors. Pneumonia-associated mortality in surgical patients remains high compared with other infections even when correcting for differences in severity of illness. Although resistant gram-positive cocci appear to be increasing in frequency, they may represent markers of severe illness rather than true pathogens. Increasing age, severity of illness, and length of stay before diagnosis were all associated with a worse prognosis.

FROM: Crabtree TD, Gleason TG, Pruett TL, Sawyer RG. Trends in nosocomial pneumonia in surgical patients as we approach the 21 st century: a prospective analysis. Ann Surg 1999;65:706-709. 